\title{
University museum seeks independence
}

[SEATTLE] One of the larger and more unusual natural history collections in the United States is considering splitting from its parent university in a move that, while symptomatic of the low academic priority often placed on traditional museum activities, could have serious repercussions for teaching and research.

The Burke Museum of Natural History and Culture in Seattle is renowned for its ornithology specimens, including the world's largest collection of extended bird wings. It plans to become independent of its current owner, the University of Washington, largely because of a lack of financial support from the university to fund a modernization and expansion project.

Officials at Burke want to build a $\$ 90$ million facility to house specimens, create new research laboratories, and increase public outreach. But university administrators say this is such a low priority that it will not be funded. A Washington law limiting state expenditure has made matters worse, and Burke officials hope to be more successful at finding funding sources as a separate entity.

"In principle, the university has been very supportive. But in practice it hasn't been able to contribute the funds we need," says Karl. L. Hutterer, Burke's director. "We came to the conclusion that it would be best for the Burke go on its own, maintaining linkage with the university through affiliation agreements."

This conclusion was reached despite the decision of a faculty-dominated committee in October that the museum should not separate from the university because of "serious, potentially very negative, consequences".

Washington provost Lee L. Huntsman says that, although it wants to maintain the "deeply treasured relationship" with the museum, the university is "feeling financially strapped" and needs to fund programmes closer to its "core mission".

Founded in 1885, the Burke museum has an annual operating budget of about \$2.6 million. It holds major collections involving mammalogy, anthropology, geology and zoology, including a genetic resources collection with unique frozen tissue specimens.

Following approval last month by the university's board of regents, Burke officials have set up a committee to determine how the museum could become a private, non-profit corporation, and to explore whether a new facility should be built on the university's main campus or at another location in Seattle. It will report by September to the regents, who must approve a separation plan.

Many systematics researchers argue that separating collections from a university has a deleterious impact on both teaching and research, hindering studies of biodiversity, ecology and comparative biology.

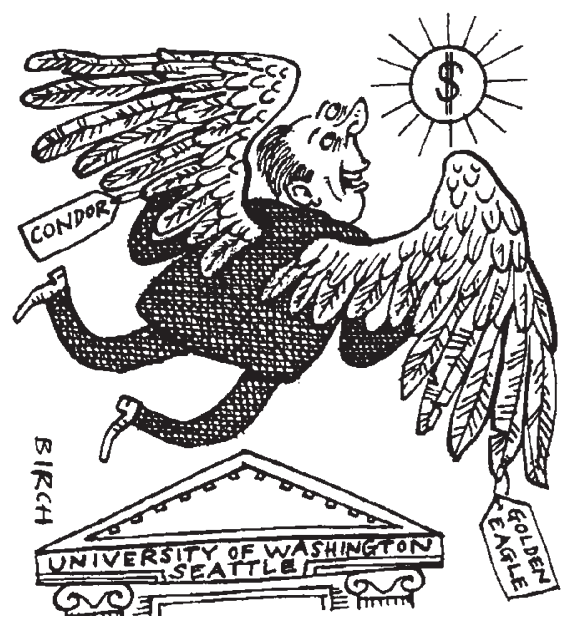

Many museums are now seeking to maximize the use of collections seen as low priorities by university executives, who have steered their institutions more towards molecular biology (see Nature 394, 115; 1998).

Earlier this month, the California Academy of Sciences and Stanford University in Palo Alto held a symposium highlighting the importance of systematics studies within museum and university communities.

One participant in favour of close ties between universities and museums is Brent Mishler, director of the University of California at Berkeley's University and Jepson Herbaria. "Those universities with the strongest programs in biodiversity are the ones with collections on campus," he says.

Ward Watt, an evolutionary biologist at with the university," says Peter B. Tirrell, associate director of the University of Oklahoma Museum of Natural History, and previous president of the Association of College and University Museums and Galleries. "There is a cumulative value of keeping research, teaching and students together."

According to Tirrell, Oklahoma conducted a similar assessment but chose to keep the museum at the university, assisted by a philanthropic drive that helped to build a new $\$ 28$ million museum. Hutterer points out that, although Seattle's economy has boomed with high-tech businesses, this has not been accompanied by such support for the Burke.
Stanford, says he was "utterly disgusted" when Stanford moved its collection to the California Academy of Sciences in San Francisco 30 years ago. He says it meant that the university did not participate fully in the revolutionary changes in systematic biology.

As scientists probe plant and animal genomes, says Watt, collections take on more importance. He calls for studies by scientists from different disciplines using new tools.

Supporters of the Burke museum acknowledge the need for such collaborations, but argue that economic realities mean the museum has little choice but to try to fashion a new course.

Rex Dalton

\section{More US labs may curb visits by foreigners}

[WASHINGTON] Fermilab, Brookhaven and the US Department of Energy's other nonweapons laboratories could be caught up in the backlash against foreign visitors to government labs which has accompanied recent allegations of Chinese spying at the Los Alamos laboratory in New Mexico.

George Nethercutt (Republican, Washington) plans to amend an energy department funding bill to restrict visits of scientists from sensitive countries, including India, China and Russia, to all the department's laboratories, including civilian ones that hold no nuclear secrets.

The amendment would not ban such visits outright, but would require the Secretary of Energy to apply for special permission for visits involving a long list of prescribed technologies. The requirement would be lifted only after extensive new security and counter-intelligence measures had been implemented at the laboratories.

James Sensenbrenner (Republican, Wisconsin), the chair of the Science Committee in the House of Representatives, said he would support the Nethercutt amendment.
Laboratories hit by the proposed regulations would include Fermilab, Brookhaven, Oak Ridge, the Stanford Linear Accelerator Center, the Pacific Northwest laboratory and most of the other major physics facilities in the United States.

The Nethercutt amendment, which was due to be considered by the Science Committee this week, was watered down from earlier versions that would have blocked most visitors from sensitive countries altogether. But the level of support for the amendment suggests that the civilian laboratories can expect, at the very least, to implement tighter security in the wake of the Los Alamos allegations.

Scientific leaders were attempting to defend scientific collaboration with foreigners in the face of what a government official describes as strong public support for tough measures to clamp down on foreign visitors and to tighten security at US government laboratories. Both the National Academy of Sciences and the National Science Board are preparing statements to defend the foreign visitors programme at the laboratories. 